\title{
Początki cenobii na Górze Poczajowskiej i pierwsze donacje na rzecz monasteru
}

\author{
ks. archimandryta Andrzej Borkowski \\ Katedra Teologii Prawosławnej Uniwersytetu w Białymstoku \\ borkowskiunath@yahoo.gr
}

\begin{abstract}
ks. archimandryta Andrzej Borkowski, The origins of Cenobitic Monasticism on Mount Pochayiv and the First Donations to the Monastery, Elpis, 16 2014: 173-181.

Abstract: Mount Pochayiv became famous in Russia after the miraculous apparition of the Mother of God, which took place there. Presumably, already in 1240, monks from Kiev found refuge in nearby caves when fleeing the Tartar hordes. In 1559, the owner of these lands Anna Hojska provided funds for building an Orthodox monastery for the monks living in the caves and gave them a miraculous icon of the Mother of God. The most prominent abbot of the Pochayiv monastery was Job Zalizo. He was first elected exclusively by the monks as the new superior of the monastery, the fourth superior since the cenobitic rule was introduced in the monastery. The second prominent founder of the Pochayiv monastery were the Domaszewska family. Their efforts in the construction of the stone church, financial, land support and earth intended for the beautification and maintenance of the monastery, was to compensate for losses and damages applied by the magnate Firlej and the Cossack uprising. They wanted to prevent the total collapse and cessation of monastic life on Mount Pochayiv. For this reason, their names are so strongly emphasized in the history of the main spiritual center of Volyn.

Streszczenie: Góra poczajowska zasłynęła na Rusi po cudownym objawieniu się tam Matki Bożej. Przypuszczalnie, już w $1240 \mathrm{r}$. uciekający przed hordami tatarskimi mnisi z Kijowa znaleźli schronienie w pobliskich pieczarach. W 1559 r. właścicielka tych ziem Anna Hojska ufundowała dla żyjących w pieczarach mnichów monaster prawosławny oraz przekazała cudowną ikonę Matki Bożej. Najwybitniejszym ihumenem monasteru poczajowskiego był św. Hiob Zalizo. Po raz pierwszy został wybrany wyłącznie przez mnichów na nowego przełożonego monasteru, czwartego od czasu wprowadzenia w monasterze reguły cenobitycznej. Drugimi wybitnymi fundatorami monasteru poczajowskiego stali się małżonkowie Domaszewscy. Swymi wysiłkami włożonymi w wzniesienie kamiennej cerkwi, znacznymi nadaniami pieniężnymi i ziemskimi przeznaczonymi na jej upiększenie i utrzymanie samego monasteru, pragnęli wynagrodzić straty i zniszczenia naniesione przez możnowładcę Firleja oraz powstanie kozackie, i tym samym nie dopuścić do całkowitego upadku i ustania życia monastycznego na Górze Poczajowskiej. Z tego względu ich imiona zostały tak mocno podkreślone w dziejach głównego ośrodka duchowego na Wołyniu.
\end{abstract}

Keywords: Job Zalizo, Pochayiv Monastery, Anna Hojska, Eva and Theodore Domaszewscy

Słowa kluczowe: Hiob Zalizo, Monaster Poczajowski, Anna Hojska, Ewa i Teodor Domaszewscy

Ślady życia monastycznego na Górze Poczajowskiej sięgają początków XIII wieku. Przypuszczalnie już w 1240 r. uciekający przed hordami tatarskimi mnisi z Kijowa znaleźli schronienie na górze poczajowskiej. Nazwa Poczajów jest skrótem od słów „Pocza - Diwa”, co oznacza, że Najświętsza Bogarodzica „Diwa” zaczęła czynić cuda. W mowie potocznej słowo "Diwa” z czasem straciło początkowe „D” i końcowe „a”. W ten sposób ze słów „Pocza - Diwa” powstała nazwa „Poczaiw”.

Dowodem na istnienie monasteru poczajewskiego są liczne podania i legendy oraz dokumenty historyczne. „Jest podanie - czytamy u M. Balińskiego i T. Lipińskiego - że w XIII wieku, mieli tu zakonnicy reguły św. Bazylego kaplicę, w małej między skałami pieczarze"' Z Z rękopiśmiennej księgi pt. Monastyr - Skit, napisanej w XVIII wieku (1732 r.) przez bazyliańskiego mnicha z Poczajowa dowiadujemy się, że założył go w 1219 r. mnich o imieniu Metody, który przybył ze św. Góry Athos³. Również w księd-

N. Tripolskij, $K$ istorii drewniago prawoslawnago Poczajewskago monastyra na Wolyni, „Wołynskija Eparchialnye Wedomosti”(dalej: „WEW”) 18 (1896) 708 - 709. Zob. J. Dubilko, The Pochaiv Monastery in the history of our nation, Vinnipeg 1986, s.16. S. Antonovič, Korotkii istoričnii naris Počaïvs'koï Uspins'koï Lavri, Kremianec 1938, s. 8 - 9.

2 M. Baliński, T. Lipiński, Starożytna Polska, Warszawa 1844, t. 2/2, s. 92.

N. Tripolskij, $K$ istorii drewniago prawoslavnago Poczajewskago ze powództw i dokumentów klasztornych z 1661 r. (t. II, s.144) oraz w Epitome historica de origine... Poczajowensi Monte i maginis... A.D.1773... jest wzmianka o nieistniejącym dziele pt. Pamiatnik monastyria Poczajewskago, które odnosi pierwotne osiedlenie mnichów na $1240 \mathrm{r}^{4}$

Objawienie widziane przez czcigodnego męża o imieniu Turkuł na Górze Poczajowskiej w 1198 r., a następnie przez Metodego było podstawą do stworzenia przez lud legendy mówiącej, że na Górze Poczajowskiej pewien człowiek widział Matkę Boską stojącą w ogniu, a przed Nią stojącego mnicha, który przepowiedział chwałę mającemu powstać na tym miejscu monasterowi. Owa legenda podtrzymywana przez bogobojny lud była w końcu opublikowana w formie rozszerzonej, jednakże nie w pełni dokładnej i wiarygodnej. W 1665 r. we Lwowie opublikowano książkę autorstwa rektora „Kijewo-Bratskago Uczyliszcza”, hieromnicha Jaonicjusza Galatowskiego „Niebo nowoje s nowymi zwiezdami". Autor wśród cudów uczynionych przez Matkę

monastyra na Wołyni, „WEW” 15-18 (1896) 570-575, 607-617, 672-675, 687-710 (o polskim rękopisie z 1702 r. znajdujemy jedynie zsyłki).

4 A. Petruszewicz, Istoriczeskoje izwiestije o drewniej Poczajewskoj obitieli, [w:] „Galiczanin”, 1 (1863) 159. Amwrosij (Łatockij) archim., Skazanije o Poczajewskoj Uspienskoj Ławre, Poczajew 1787, s.14. A. Chojnacki, Prawosławije na Zapadie Rossii ili Patieryk Wołyno - Poczajewskij, Moskwa 1888, s. 35. 
Boską opisuje Jej objawienie w słupie ognia na skale Góry Poczajowskiej. Szczegółowo opisuje to wydarzenie, twierdząc, że widział je człowiek o imieniu Jan Bosy ze wsi Poczajów oraz mieszkający tam mnich, który powiadomił go i znajdujących się nieopodal pastuszków, że Najświętsza Bogarodzica pozostawiła ślad swojej stopy na skale, że w tej stopie zawsze znajdować się będzie czysta woda, cudownie uzdrawiająca od wszelkich chorób, i wreszcie, że na tej skale zostanie wybudowana kamienna cerkiew, a przy niej sławny monaster otoczony kamiennym murem, który od wsi Poczajów zostanie nazwany Poczajowskim ${ }^{5}$. Chociaż daty tego cudu nie podano jednak z książki pt. Opisanije Poczajewskija Uspienskija Ławry dowiadujemy się, że cud miał miejsce w $1261 \mathrm{r}^{6}$

Pierwszymi dokumentami historycznymi o monasterze poczajowskim są: uniwersał Króla Zygmunta I Starego z 1527 r. do Starosty Krzemienieckiego, zabraniający ostatniemu: „aby nie mieszał się do jarmarków (odbywających się 15-go sierpnia), danin nie wybierał i sądów nie składał" - wydany na ręce Bohdana Senkowicza Hojskiego ${ }^{8}$ oraz uniwersał z 1557 r. ${ }^{9}$, wydany Bazylemu, synowi Bohdana Hojskiego, przez Zygmunta II w swej treści potwierdzający poprzedni z $1527 \mathrm{r}$. Obydwa dokumenty świadczą o starożytności monasteru poczajowskiego ${ }^{10}$ oraz o istnieniu już wtedy małej kamiennej cerkwi ku czci Wniebowzięcia Bogarodzicy, wybudowanej na miejscu drewnianej.

Pierwszą, która złożyła na rzecz monasteru hojne dary była Anna z Kozińskich ${ }^{11}$ Hojska sędzina Łucka. Zamężna

\footnotetext{
Joanicjusz Galatowski, Niebo nowoje s nowymi zwiezdami, Lwow 1665 , s. 99, cud 20; Gora Poczajewska, Poczajew 1806, k.2 verso.

6 Opisanije Poczajewskija Uspienskija Ławry, Poczajew 1878, s.32.

Pamiatniki izdannyje wremiennoj Komisijej dla razborki drewnich aktow wysoczajsze uczreżdennoju pri Kiewskom wojennom, Podol'skom $i$ Wolynskom general-gubernnatore (dalej: PVK), t. IV/2, Kijew 1859, nr. 73, s. 227. M. Baliński, T. Lipiński, Starożytna Polska, t. 2/2, s. 92.

Pierwszy z rodu Hojskich (Hośccy, Hostscy) herbu kierdeja z Hoszczy na Wołyniu, o którym posiadamy informacje. W 1488 r. zostaje mianowanym podczaszym litewskim i klucznikiem łuckim, a w 1492 już tylko klucznikiem łuckim. W 1494 r. otrzymał od Aleksandra Jag. Zwierów w powiecie łuckim, a w 1495 ustanowił mu targi w Hoszczy. W 1528 r. dostarczył na potrzeby wojenne trzy konie, a jego syn Bazyli siedem. Oprócz Bazylego miał jeszcze synów Aleksandra i Jana oraz córkę Juliannę. Zob. A. Boniecki, Herbarz Polski, t. VII, W - wa 1904, s. 361-362.

9 Dierżawnyj Archiw Tarnopolskoj Oblasti (dalej: DATO), Fond 258 (Počaevski Arhiv), opis 3, sprawa nr 1165/1: Dieło o fondie pożertwowanija zawieszczannogo Poczajewskomu monastyru Annoj Gojskoj, t. I (1557 1725), k. 86 - 87. Uniwersał królewski z 1557 r.

${ }_{10}$ Amwrosij (Łatockij) archim., Skazanije o Poczajewskoj Uspienskoj Lawre, Poczajew 1787, s. 14-15.

11 Według A. Bonieckiego istniały dwa domy o tym nazwisku na Wołyniu: jeden herbu kierdeja, a drug właściwie herbu własnego. Heraldycy zwą go Zagłobą, tym się jednak różni od niego, że miecz nie przeszywa podkowy ale umiejscowiony jest prosto ostrzem w górę nad nią, a w szczycie chełmu znajduje się nie skrzydło, a trzy strusie pióra. Siedzibą Kozińskich h. własnego był Kozin w powiecie krzemienieckim. W 1528 r. przekazali na potrzeby wojenne 17 koni. Hryńko Koziński, w 1494 r. chorąży łucki, miał czterech synów: Olechnę, Michnę, Tyszkę (Tychnę) i Seńka. Tychno Hryńkowicz, od 1513 r. dworzynin królewski, otrzymał w 1527 r. ekspektatywę na styrostwo owruckie, ale go nigdy nie posiadał. W 1511 r. król Zygmunt potwierdził darowiznę Klipowszczyzny i Diczówki w powiecie owruckim, przekazaną mu przez teścia. Żonaty z Jewfimia, z którą miał synów: Filipa, Olechnę i Michała oraz córkę Anne żonę Jerofieja Hośćkiego, sędziego ziemskiego łuckiego. Zob. Boniecki,
} Herbarz Polski, t. XII, s. 91 z synem Bazylego Hojskiego (Hostskiego) Jerofiejem, rotmistrzem królewskim (w $1576 \mathrm{r}$. mianowany starostą łuckim, a w 1580 sędzią ziem łuckich), który w 1565 i 1568 r. sporządził jej zapis. W 1578 r. zapisal jej 3 tys. kop litewskich groszy w długach na Poczajów wraz z przylegającymi do niego majątkami oraz darował jej trzecią część swych dóbr miasta Krupe ${ }^{12}$. Umarł bezdzietny w 1581 r. Jego siostra Łosiatyńska pozwała bratową do sądu w sprawie dóbr po bracie. Przegrawszy jednak sprawę zawiera z nią w 1585 r. ugodę, odsprzedając jej swe prawa do dóbr Poczajowskich ${ }^{13}$. Podczas pobytu greckiego biskupa Neofita w jej domu, Anna otrzymuje w dowód wdzięczności ikonę Matki Boskiej (w 1559 r.), która wkrótce zasłynęła licznymi cudami. Po tym jak ślepy od urodzenia jej brat przejrzał, ikona uroczyście została przeniesiona w 1597 r. do cerkwi Zaśnięcia Bogarodzicy i ofiarowana monasterowi, a sama Anna robi hojny zapis w Ziemstwie Krzemieniec$\mathrm{kim}^{14}$. W testamencie daje wyraz swego przywiązania do wiary prawosławnej: „Umysliła jesmy Monastyr zbudowati i jego fundowati takim obyczajem, aby u tom monastyri Czerniecow ludiej dobrych pobożnago żywota nie jakago inszago zakonu, tylko Greczeskago Wostocznoj cerkwi posłuszeństwa liczboju osiem diakow dwa ...” („Uczreditielnaja gramota ili funduszowaja zapiś A.Gojskoj na ustrojstwo monastyra") $)^{15}$.

Według pierwotnych źródeł monaster poczajowski pozostawał pod bezpośrednim protektoratem fundatorki Anny Hojskiej. Pomimo, iż w swym fundacyjnym zapisie cały majątek przekazuje swym ulubieńcom, wnukom Andrzejowi i Iwanowi Firlejom, tym nie mniej założony przez nia monaster pozostawia w swej bezpośredniej dyspozycji. „Odnak wsie inszyje kondycyje nad dożywotnoje używanie mnie i monastyrom, w tym że zapisie trybunalskim worowansze - mowi w swym testamencie z 21 października 1611 r. w swojej zupolnoj mocy zostawuju i onych ostieregaju czasy wiecznymi tak w swojej mocy zostawaty majet"16. Można przypuszczać, iż zakres wpływów na monaster ograniczał się jedynie do działalności dobroczynnej oraz ochrony przed uciskami z zewnątrz. W wewnętrzne życie wspólnoty Anna Hojska nie ingerowała, w każdym razie nie posiadamy dokumentów, które mogły by temu zaprzeczyć.

Historia zachowała niewiele swiadectw o działalnosci pierwszego ihumena metropolity Neofita, jak również

DATO, F. 258 op 3,1165/1: Dieło o fondie pożertwowanija zawieszczannogo Poczajewskomu monastyru Annoj Gojskoj. T. I (1557 1725), k. 109 - 112.

13 Tamże, k. 118 - 119. Umowa o odsprzedaży przez Łosiatyńską swych praw do dóbr Poczajowskich Annie Hojskiej za kwotę 10 tys. kop litewskich groszy.

14 Boniecki, Herbarz Polski, t. VII, s. 362, t. XII, s. 91 - 92.

$15 P V K$, t. IV/1, nr. 28, s. 173-175. Zob. W. Lewickij, $K$ woprosu o wremieni osnowanija Poczajewskoj Lawry i o pierwoj ustroitielnice jeja Annie Gojskoj, „WEW” 6-11 (1913) 96-100, 126-128, 138-142, 165-167, 201-204. A. Borkowski, Dzieje drukarni poczajowskiej, [w:] Klasztory i kultura krajów słowiańskich, red. W. Stępniak-Minczewa, Z. J. Kijas, Kraków 2001, s. 280-281.

16 Testament Anny Hojskiej z 21. X. 1611 r. K woprosu o wremieni osnowanija Poczajewskoj Ławry i o pierwoj ustroitielnice jeja Annie Hojskoj, „WEW”, 8 (1913) 42. 
dwóch następnych Cypriana i Teodora. Pierwszy po śmierci Anny Hojskiej zabrał z monasteru utynsylia kościelne oraz księgi liturgiczne, po czym przeniósł sie do monasteru Św. Spasa w Dubnie ${ }^{17}$. Dwaj pozostali byli przełożonymi klasztoru bardzo krótko i poza postawionym zarzutem ze strony właściciela Poczajowa, Andrzeja Firleja o niewłaściwym nadzorze majątku klasztornego, nie pozostawili żadnych śladów swej działalności ${ }^{18}$.

Głównym organizatorem życia monastycznego na Górze Poczajowskiej był św. Hiob Zalizo (przed przyjęciem ślubów mniszych i w schimie Jan). Bez wyolbrzymiania można stwierdzić, iż św. Hiob był dla monasteru poczajowskiego tym, czym św. Teodozjusz Peczerski dla Ławry Kijewo - Peczerskiej a św. Sergiusz dla Ławry Trojce -Siergiejowskiej.

Czas przejścia św. Hioba do Poczajowa nie jest dokładnie ustalony. Zgodnie z wcześniej przytoczonym stanowiskiem N. Pietrowa miałby to być 1598 r. $^{19}$. A. Chojnacki określa tą datę na lata 1602-1603, uważając go za pierwszego ihumena poczajowskiego ${ }^{20}$. Opublikowane jednak przez B. Lewickiego w 1912 r. akty monasteru Poczajowskiego rzucają nowe światło na czas mianowania go na przełożonego w Poczajowie, ukazując równocześnie, że poprzedzili go inni ihumeni.

W dniu 12 grudnia 1647 r. sąd polubowny prowadził dochodzenie na gruntach monasteru poczajowskiego, w sprawie ustalenia jego granic z gruntami Andrzeja Firleja. Komisja sądowa przesłuchiwała w tej sprawie licznych świadków. Jednym z nich był niejaki Piotr Lada, który zeznał pod przysięgą, że przed św. Hiobem ihumenami monasteru byli Neofit, Cyprian i Teodor. „W roku jeszcze 1611, kiedy Kozin objął j.m.p. Bełzski, był z j.m.p. Bełzskim u babki jego jey mości Pani Hosckiey y z nią pospołu byli na odpuście w monasterze Poczajowskim, był y drugi raz, kiedy roku pańskiego tysiąc sześćset trzynastego zapisywała te majętności j.m.p. Bełzskiemu w Krzemieńcu, tedy tym duktem którym j.m.p. Bełzski prowadził, oraz na ten czas opisywała ograniczenie monasterskie pospołu z panem Makarym Liduchowskim, był w ten czas yhumenem grek, u którego na j.m.p. Bełzskiego targował gumno, bo nie dostawało na sztuky zboża j.m. panu Bełzskiemu, ten i chował

\footnotetext{
17 Materialy po istorii Poczajewskoj Ławry (dalej: MIPL), red. W. Lewickij, t. 1, Poczajew 1912, nr. 4, s. $7-8$.

18 „... według zwyczaju dawnego, według reiestru od Ihumena na tenczas bedącego te rzeczy do seguestatu swego dla inkwisyi częstych tatarskich i dla tego, aby to nie gineło odebrał, bo ten zwyczaj bywał iz dziedzicowie wszędy do schowania brali, a po tym na swięta wielkie, uroczyste do cerkwi dla nabożenstwa dawali; gdyż przed tym Ihumenowie wielkie szkody $\mathrm{w}$ apparatach czynili, i nie mało rzeczy przez niedozor gineło, zaczym teraźniejszy pozwany, iako dziedzic i colator tego monastera, strzegąc tego, by i dalsza uyma nie była z wolą, i wiadomością wszystkich czerncow, odebrał był...” . DATO, F. 258 op 3, sprawa nr 1169: Wypisi iż grodskich Kremienieckich aktowych knig (1642 - 44), k. 217 - 39. Dekret sędzi treciejskiego w sprawie rozpatrzenia skarg Monasteru Poczajowskiego przeciwko Andrzejowi Firlejowi z 5. IX. 1644 r; MIPL, nr. 64, s. 142.

19 Pczeła Poczajewskaja. Izbornik nazidatel'nych pouczenij i statej, sostawlennych i spisannych prepodobnym Iowom, igumenom Ławry Poczajewskoj (1581-1651) (dalej: Pczeła Poczajewskaja), red. prof. N. I. Pietrow, Poczajów 1884, s. 31.

20 A. Chojnacki, Prawosławije na Zapadie Rossii, s. 147.
}

p. Hoscką; po nim Kiprian, po tym Feodor byli yhumenami niedługo, a za tymi teraznieyszy yhumen ociec Zelizo"21.

Wkrótce po przybyciu do Monasteru Poczajowskiego zostaje wybrany ihumenem. Trudno ustalić dokładny czas jego wyboru ze względu na brak jakichkolwiek danych. Możemy jednak w przybliżeniu określić czas objęcia przez niego tego stanowiska, nie wcześniej niż w 1620 r. i nie później niż w 1623 r. Wiadomo, że do 1619 r. (tj. do czasu śmierci bogobojnej fundatorki Anny Hojskiej) przełożonym był grecki metropolita Neofit, następnie niedługo Cyprian i Teodor. Czwartym z rzędu był św. Hiob Zalizo.

Akt sądowy z 20 listopada 1641 r. dotyczący sporu między mnichami poczajowskimi a Danielem Grudnickim - pełnomocnikiem Andrzeja Firleja, w sprawie grabieży monasteru nadmienia, że miała ona miejsce w $1623 \mathrm{r}$., tj. w okresie pełnienia funkcji ihumena przez św. Hioba, „za ihumena powoda tiepiereszniaho (św. Hioba) w roku proszłom tysiacza szestsot dwadcet' tretiem"22.

Zgodnie z darowizną Anny Hojskiej ihumen Monasteru Poczajowskiego powinien być wybierany przez właścicieli Poczajowa, bądź fundatorów pospołu s czerncami ${ }^{23}$. $\mathrm{W}$ podobny sposób odbyły się wybory dwóch pierwszych ihumenów Cypriana i Teodora. Z zachowanych dokumentów dowiadujemy się, że spadkobierca Andrzej Firlej nadużywając prawa ktitorstwa lekkomyślnie rozporządzał majątkiem monasteru. Pod pretekstem zagrożenia częstymi najazdami Tatarów, oraz nie zawsze rzetelnym postępowaniem byłych ihumenów zabrał do Zamku Kozińskiego utensylia Kościelne, spośród których wiele już nigdy nie wróciło do swego prawowitego właściciela ${ }^{24}$.

W całkiem innych uwarunkowaniach odbyły się wybory św. Hioba na stanowisko przełożonego, nie przez właściciela pospołu s czerncami, lecz wyłącznie przez mnichów ot inokow usierdnym proszenijem. Po objęciu funkcji ihumena natychmiast odsunął ktitora, protestanta Andrzeja Firleja od jakichkolwiek ingerencji w życie wspólnoty. Dlatego w całym szeregu dokumentów, dotyczących sporu możnowładcy $\mathrm{z}$ monasterem poczajowskim spotykamy jego uporczywe zarzuty w niewłaściwym wyborze przełożonego, „iż nie pokazujet inwestytury swoi na ihumenstwo ot

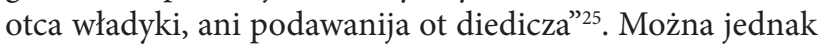
przypuszczać, że był krótki okres, kiedy Firlej żył w zgodzie

\footnotetext{
21 MIPL, nr. 81, s. 169.
}

22 DATO, F. 258 op. 3, sprawa nr. 1168/2: Sudiebnoje dieło s naslednikami Anny Gojskoj - Firlejami w swiazi s naruszenijami imi zawieszczanija Anny Gojskoj w polzu monastyra (9. III. - 10. XII. 1641), k. 50 - 90. Protest pełnomocnika Andrzeja Firleja - Daniela Grudnickiego do Sądu Ziemskiego w Krzemieńcu przeciwko skierowanemu przeciwko niemu oskarżeniu mnichów poczajowskich o grabieży monasteru. $M I P L$, nr. 31, s. 57.

23 DATO, F. 258 op. 3, sprawa nr 1163/22a: Zurnat registracii sobytij i dokumentacii monastyra - chronika monastyra (1557 - 1799), k. 4. Zapis Anny Hojskiej z 14. VII. 1597 r.

24 DATO, F. 258 op 3, sprawa nr 1169: Wypisi iż grodskich Kremienieckich aktowych knig (1642 - 44), k. 217 - 39. Dekret sędzi treciejskiego w sprawie rozpatrzenia skarg monasteru poczajowskiego przeciwko Andrzejowi Firlejowi z 5. IX. 1644 r. MIPL, nr. 64, s. 142.

25 DATO, F. 258 op. 3, sprawa nr 1168/2: Sudiebnoje dieło s naslednikami Anny Gojskoj - Firlejami w swiazi s naruszenijami imi zawieszczanija Anny Gojskoj w polzu monastyra (9. III. - 10. XII. 1641), k. 38 - 39, 50. MIPL, nr. 30 , s. 54 ; nr. 31 , s. 59 
z monasterem, a nawet mu sprzyjał. Uznał św. Hioba, jako ihumena monasteru oraz upełnomocnił do zarządzania wszystkimi cerkwiami wraz $\mathrm{z}$ ich majątkami, znajdującymi się na terenie jego posiadłości. Św. Hiob nie omieszkał użyć tego argumentu wobec pozwanego Firleja, „że aktor (powód) nie jest ihumenom, tedy aktor tiepieresznyj prez let dwadcat' i kilka tam w tom monastyre Poczajewskom, ale i swieckich duchownych w dobrach storony pozwanoje za prozboju i poruczenijem sobie w zawiedowan'ju ot czasu niemałoho mieł, czoho dowodiaczy, pokazała storona powodowaja list s pieczat'ju i podpisom ruki pozwanoje storony do duchownych swieckich i majetnostiach pozwanoje storony Poczajewskaho wo wsiem, posłuszni byli”26.

Dobre stosunki pomiędzy monasterem a Andrzejem Firlejem nie trwały zbyt długo. Samodzielny system działalności nowo wybranego ihumena był sprzeczny z religijnymi poglądami wrogo nastawionego do ideałów życia ascetycznego magnata. Nie obeszło się bez poduszczeń ze strony protestanckich nauczycieli. Jak świadczy akt Koronnego Sądu Trybunalskiego Firlej starał się, „aby honor prebłahosłowiennoje panny sztodiennoje swoje bieruczy pomnożen’je mieży ludmi rozmaitoho stanu i roznoje wokacyje w sercach jako najhłubiej wkoreniwszy, ałtisimie za ich pracoju pri błahosłowinstwie bożom a pryczynoju naswiatszoje Bohorodicy osobliwoje tohoż miesca i wsieho obraz zakonu protiektorki i miłostiwoje pannie patronki i dobrodiejki krewiłsie, jako najbarziej mogł poruszonyj i nader omylnoju swoich starszych uczycielew namowoju, kotoryje dobra Bohu i preczystoj Bohurodicy poszlublenyje i powieżonyje zniszczyt' zamyszlali, takowoje radi jeho miłosti Pan Bielzskij usłuchawszy, wytisnuti s toho swiatoho miesca prereczonych zakonnikow i tot ołtar panskij i nabłahosłowienszoje Panny Maryi zatym diedictwo wniwecz obiernuti usiłowali"27. W 1623 r. Andrzej Firlej korzystając z przysługującego mu prawa patronatu oraz bezprawnego położenia monasterów prawosławnych w państwie Polsko - Litewskim, wysłał sługę Grzegorza Kozińskiego w celu odebrania depozytu Monasteru Poczajowskiego.

Ciągłe prześladowania zrodziły u św. Hioba myśl o opuszczeniu granic Królestwa. Widać to z listu do cara Michaiła Teodorowicza, napisanym 1 maja 1626 r. i wysłanym przez mnicha poczajowskiego Ignacego. „Pomyslich ubo i żełach ot mnoha wremieni i Boha mojeho usierdno molich, abym sam mogł osoboju mojeju pokłonitisia noham wieliczestwa ti, hosudaru mojemu, i widieti preswietłoje lice Anhielskoje, Bohom wożdielennyj hosudaru, prawosławnyj caru Michaił Fieodorowicz... A iż po niegodnosti mojej ni zdradił mi Hospod' Boh i dla nużnych radi potreb monastyrskich, nie biez wielikaho żalu i utisnienia, łasce Boha mojeho i czasowi sczasliwszemu to zostawiwszy"28.

\footnotetext{
DATO, F. 258 op. 3, sprawa nr 1168/2, k. 89. MIPL, nr. 32, s. 63.

Tamże, sprawa nr 1170 /4: Wypisi iz Kremienieckich ziemskich knig kontraktow, dekretow $i$ sudiebnych dieł po ziemielnym i dienieżnym sporam s pomieszczykami Bielzskimi, Firlejem i drugimi. t. I (1644 - 46), k. 40 - 41. Odpis z aktu Koronnego Sądu Trybunalskiego w Lublinie z 27. VI. 1646 r. MIPL, nr. 74, s. 161 .

28 MIPL, List św. Hioba Poczajowskiego do cara Michaiła Teodorowicza Romanowa, s. 184
}

Z przytoczonego tekstu widać, w jakim żałosnym położeniu znajdował się wówczas monaster poczajowski. Św. Hiob rysuje przed carem obraz strawionego przez pożar majątku monasterskiego, otoczonego przez licznych wrogów, opuszczonego, bez oparcia w prawosławnej magnaterii i możnowładztwie. „Pożałuj, pożałuj, pożałuj, prawosławnyj hosudaru, caru i wielikij kniaz’ Michaił Fieodorowicz (z jego ust wyrywa się żałosne wezwanie), nas niehodnych bohomolcow swoich i obitiel naszu Uspienija Preswiatyja Bohorodicy i prysnodiewy Maryi, kotoraja s dopuszczenija Bożoho obitiel, swiataja, mienowitie, ukrasa cerkownaja, odieżda swiaszczenniczeskaja: Jewanhielija, kresty i obrazy i proczije błaholepije cerkownoje ohniem shoreło, kotoroje wsie ot predkow wieliczestwija Twojeho i ot ktitorow drewnich błahoczestiwych nadano było. Wsich że czasiech mohu reszczy w naszych krajach nie szczasliwych takowyja nie tolko utnalilis', ale otniud nie obretajutsia..."29.

W monasterskich dokumentach nie znajdujemy informacji o wspomnianym pożarze monasteru oraz o darach ze strony przodków cara Michaiła Teodorowicza ${ }^{30}$. Nie musimy za to szukać daleko dowodów na poparcie faktu na zwiększającą się nietolerancje wobec prawosławia. Rezultatem powyższej sytuacji była, poczynając od I połowy XVII w. postępująca szybka konwersja $\mathrm{z}$ prawosławia na rzymski katolicyzm oraz polonizacja wybitnych prawosławnych ruskich rodów. Już Książę Konstanty Ostrogski miał nieszczęście widzieć w swej rodzinie renegata prawosławnej wiary, w osobie swego syna Janusza. Inni, starając się złagodzić swe odstępstwo przyjmowali unię. Żałosne położenie Kościoła prawosławnego w Rzeczypospolitej oraz jego smutek z powodu odstępstw niektórych znaczących prawosławnych rodów z wyjątkową siłą wyraził Melecjusz Smotrycki w utworze Thrinos (lament) z 1610 r. W imieniu Kościoła prawosławnego zwracał się ku odstępcom w następujących słowach: „Gdie tiepier nieoceniennyj kamien’ kotoryj ja nosiła wmiestie $\mathrm{z}$ drugimi brilliantami na mojej hławie...” ${ }^{31}$. Z pasją i klątwą na ustach zwracał się do nich Melecjusz Smotrycki, ponieważ nie tylko sami wyrzekli się wiary ojców, łatwo ulegając latynizacji, ale następnie krzewili unię wśród swych poddanych.

Trudne położenie Prawosławia w Rzeczypospolitej skłoniło wielu z nich do porzucenia jej granic. W $1625 \mathrm{r}$. emigrował z wołyńskiego monasteru w Dermaniu biskup brzeski Józef Kurcewicz. Podobną chęć wyraził metropolita kijowski Izajasz Kopiński. W 1638 r. z monasteru w Hu-

\footnotetext{
29 Tamże.

30 Pod darami możemy rozumieć zrabowane przez Firleja „Ewanhielije Moskowskoje, blachami srebrnymi miesto diech oprawnyje oraz misku srebrnuju moskowskuju". Ofiarowali je jednak Michał i Adam Wiśniowieccy oraz księżna Marusia Zbarażska. Zob. DATO, F. 258 op. 3, sprawa nr 1168/2: Sudiebnoje dieło s naslednikami Anny Gojskoj - Firlejami w swiazi s naruszenijami imi zawieszczanija Anny Gojskoj w polzu monastyra (9. III. - 10. XII. 1641), k. 21 - 22. Odpis z ksiąg grodzkich krzemienieckich zawierający skargę ihumena Poczajowskiego Hioba Zelezo przeciwko Kasztelanowi Bielskiemu Andrzejowi Firlejowi za nasłanie na monaster Grzegorza Kozińskiego w celu zagarnięcia cudownej ikony Matki Boskiej Poczajowskiej oraz jego majatku. MIPL, nr. 26, s. 45.

31 P. N. Batiuszkow, Wołyń. Istoriczeskija sud'by Jugo - Zapadnago kraja, S - Petersburg 1888, s. 124.
} 
styniu wraz z ihumenem przeszło na tereny Państwa Moskiewskiego około siedemdziesięciu mnichów, dwudziestu nowicjuszy i 11 chłopskich rodzin, przypisanych do klasztoru; z żeńskiego monasteru w Ladyniu: duchowy opiekun Metody, ihumenia Elżbieta, 30 sióstr z szesnastoma służkami; z monasteru w Dubnie wyszło czternastu mnichów ${ }^{32}$. Wcześniej, bo w 1592 r. bractwo lwowskie w liście skierowanym do moskiewskiego cara Teodora Joanowicza wyraziło swe rozgoryczenie z powodu prześladowań, osamotnienia oraz braku obrońców wiary prawosławnej ${ }^{33}$. Ów niepokój wyraził w swym liście do cara Michaiła Teodorowicza również św. Hiob Zalizo.

Istnieje prawdopodobieństwo, iż powodem napisania listu do cara było przybycie do Moskwy w $1625 \mathrm{r}$. z monasteru w Dermaniu biskupa włodzimiersko - brzeskiego Józefa Kurcewicza, poszukującego azylu przed prześladowaniami ze strony lacinników $w^{34}$. Car Michaił Teodorowicz wraz z patriarchą Filaretem (Nikiticzem) przyjęli życzliwie i hojnie obdarowali biskupa oraz jego świtę, składającą się z pięćdziesięciu osób. W liczbie przybyłych znajdowało się 3 hieromnichów z monasteru poczajowskiego: Antoni, Teofilakt i Ignacy. W sierpniu, po uroczystym przyjęciu, część świty biskupa Józefa powróciła do Rzeczypospolitej. Hojnie obdarzony powrócił także hieromnich Ignacy, o którym św. Hiob wspomina w liście do cara: „kotoryj (Ignacy) sożywszy so mnoju, szczasliwszym został, iż był dostoin $\mathrm{z}$ episkopom Iosifom Kurcewiczem swietle lice twoje ohladati, i diesnicu twoju obłobyzati, a noham twoim pokłonitis', i miłostyniu hodnuju otniesti” ${ }^{35}$. Carska szczodrość skłoniła św. Hioba do zwrócenia się z listowną prośbą o okazanie materialnego wsparcia monasterowi za pośrednictwem, wspomnianego wcześniej hieromnicha Ignacego: „do obitieli swiatoje (Poczajowskiej) i sodrużestwa naszeho nawiernuwszysia obaczywszy wielikuju niszczetu i nużnyi potreby obitili swiatoje, i inszoho, za mnożeniem protiwnikow błahoczestija i umalenijem synow cerkwi naszeja, poratowania snadniejszaho nie upatrujuczy..."36. W skład delegacji wchodzili także hierodiakon Józef, Grzegorz i inni. Niestety nie znamy rezultatów tego listu.

Pogrążony w trudach organizacji swej wspólnoty św. Hiob tym nie mniej bacznie obserwował i reagował na ówczesne wydarzenia w życiu Kościoła prawosławnego. Wracający przez ziemie ukraińskie z Moskwy patriarcha jerozolimski Teofanes wysłał 13 sierpnia 1620 r. pismo okrężne, w którym zwrócił się do prawosławnej ludności Litwy i Korony, aby wybrali spośród siebie biskupów ${ }^{37}$. Pod koniec sierpnia w monasterze pieczerskim odbył się zjazd ducho-

\footnotetext{
32 S. Gołubjew, Kijewskij mitropolit Pietr Mohiła i jego spodwiżniki, t. II, Kijów 1898, s. 25.

33 Akty Zapadnoj Rossii, t. IV/1, nr. 34. K. Charlampowicz, Iosif Kurcewicz, archijepiskop Suzdalskij, Kazań 1900, s. 15.

34 K. Charlampowicz, Iosif Kurcewicz, archijepiskop Suzdalskij, s. 17.

35 MIPL, List św. Hioba Poczajowskiego do cara Michaiła Teodorowicza Romanowa, s. 184.

36 Tamże.

37 M. S. Hruszewśkyj, Istorija Ukrajini - Rusi, t. VII, Kijiw-L'wiw 1909, s. 435 - 436; K. Chodynicki, Kościót prawosławny a Rzeczypospolita polska. Zarys historyczny 1370-1632, Warszawa 1934, s. 426; A. Mironowicz, Kościół prawosławny w dziejach dawnej Rzeczypospolitej, Białystok 2001, s. 80.
}

wieństwa i świeckich, na którym wybrano kandydatów na metropolitę i biskupów diecezjalnych. Pod ochroną wojsk kozackich i hetmana Wojska Zaporoskiego Piotra Zahajdacznego, patriarcha w październiku wyświęcił na metropolitę kijowskiego Hioba Boreckiego. W miesiąc później Teofanes wyświęcił na arcybiskupa połockiego znanego autora utworów polemicznych Melecjusza Smotryckiego ${ }^{38}$.

Po zabójstwie 12 listopada 1623 r. w Witebsku unickiego arcybiskupa połockiego Jozafata Kuncewicza ${ }^{39}$, winą moralną za jego śmierć obarczono Melecjusza Smotryckiego, rywalizującego $\mathrm{z}$ nim na terytorium arcybiskupstwa. Powyższe wydarzenie spowodowało wzrost nastrojów antyprawosławnych i w następstwie doprowadziły do jego wyjazdu na Wschód do Konstantynopola, Jerozolimy i Antiochii. Dążący do wzmocnienia pozycji ordynariuszy diecezji wystarał się o wydanie przez patriarchów konstantynopolitańskiego i jerozolimskiego dekretów znoszących przywileje stauropigialne bractw w Rzeczypospolitej ${ }^{40}$.

W 1627 r. arcybiskup połocki w tajemnicy złożył zwierzchnikowi Kościoła unickiego, Welaminowi Rutskiemu, deklarację o przystąpieniu do unii. Przez następny rok próbował do niej nakłonić metropolitę Boreckiego i archimandrytę monasteru pieczerskiego Piotra Mohyłę. Dnia 26 maja 1628 Hiob Borecki swym posłaniem wezwał wiernych i duchownych na wyznaczony na 15 sierpnia synod do Kijowa $^{41}$, poświęcony sprawom wewnętrznym Cerkwi. Synod stał się jednak areną dyskusji nad Apologia Smotryckiego, w której autor otwarcie opowiadał się za uniąa ${ }^{42}$. Jego praca została potępiona przez uczestników synodu, a episkopat prawosławny wydał $\mathrm{w}$ tej sprawie specjalne oświadczenie ${ }^{43}$, podpisane min. przez biorącego w nim udział św. Hioba ${ }^{44}$.

J. P. Orłowski, Uczastije Zaporożskich kozakow $w$ wostanowlenii ijerusalimskim patriarchom Teofanom prawosławnoj jużno - russkoj cerkownoj ijerarchii w 1620 g, [w:] „Trudy Kijewskoj - Duchownoj Akademii", Kijew 1905, s. 648; J. Pelesz, Geschichte der Union der ruthenischen Kirche mit Rom von den ältesten. Zeiten bis auf die Gegenwart, t. II, Würzburg-Wien 1881, s. 145 - 148; Hruszewśkyj, Istorija Ukrajini Rusi, t. VII, s. 426 - 437; D. Doroszenko, Narys istoriji Ukrajiny, Warszawa 1932, t. I, s. 206 - 207; K. Chodynicki, Kościół prawosławny..., s. 425 - 429; J. Woliński, Polska i Kościół prawosławny. Zarys historyczny, Lwów 1936, s. 72 - 73; W. Tomkiewicz, Cerkiew dyzunicka $w$ dawnej Rzeczypospolitej Polskiej 1596-1795, „Przegląd Powszechny”, CIC (1921-1922) 161 - 163; L. Bieńkowski, Organizacja Kościoła wschodniego w Polsce, [w:] Kościół w Polsce. Studia nad historią Kościoła Katolickiego w Polsce, red. J. Kłoczowski, t. 2/2, Kraków 1969, s. 843 - 844; W. A. Serczyk, Na dalekiej Ukrainie. Dzieje Kozaczyzny do 1648 roku, Wrocław-Kraków 1984, s. 188 $-189$.

39 O życiu i śmierci Jozafata Kuncewicza por. J. Susza, Cursus vitae et certamen martyrii B. J. Kuncevicii, Romae 1665; F. Konieczny, Święci w dziejach narodu polskiego, Kraków - Warszawa 1985, s. 295 - 341.

40 A. S. Osinskij, Mieletij Smotrickij, Kijew 1912, s. 86.

41 Archeograficzeskij Sbornik Dokumentow, Wilna 1904, t. II, s. 39; A. Mironowicz, Kościół prawosławny..., s. 89.

42 M. Smotrycki, Apologia Peregrynatiey do Krajów Wschodnich, przez mię Melecjusza Smotryckiego M. D. Archijepiskopa Połockiego 1626 r. $w$ Dermaniu. Zob. T. Grabowski, Ostatnie lata Melecjusza Smotryckiego. Szkic do dziejów literatury unicko-prawosławnej wieku XVIII, [w:] Księga pamiątkowa ku czci Bolesława Orzechowicza, Lwów 1916, s. 318 - 321.

43 Przebieg synodu w Kijowie został omówiony w anonimowym otworze Apolleja Apologii, wyd. w Kijowie w 1628 r.; S. Gołubiew, Kijewskij mitropolit Pietr Mogiła i jego spodwiżniki, Kijew 1898, t. I, dod. nr. 66, s. $302-317$.

44 Św. Hiob podpisał się swym imieniem zakonnym w schimie „Jan 
Znaczącą donacją na rzecz monasteru poczajowskiego była fundacja cerkwi Św. Trójcy przez Ewę i Teodora Domaszewskich $^{45}$. Nie posiadamy historycznych danych wskazujących na dokładny czas ukończenia prac budowlanych nad nową cerkwią oraz jej wyświęcenia. Z testamentu z 20 maja 1649 r. wynika, że była już zakończona. W wznoszeniu nowej świątyni brał udział św. Hiob z bracią monasterską. Zajmowali się wyrębem lasu, potrzebnego na budowie oraz wypalali wapno ${ }^{46}$. Prawdopodobnie brali również udział $\mathrm{w}$ przygotowaniach niezbędnych przy budowie kamiennej cerkwi cegieł. Domaszewscy zadbali, aby była zaopatrzona $\mathrm{w}$ niezbędne utensylia kościelne, gdyż poprzednie zostały zrabowane przez Firleja i przepadły bezpowrotnie podczas pożaru Zamku Kozińskiego. W tym celu ofiarowali 16500 zł na zakupienie niezbędnego wyposażenia cerkwi Św. Trójcy. W swym testamencie zaznaczają, że: „żadnoje czasti z nich (tzn. z zapisanej sumy) sobie, a ni potomkom swoim nie zostawujuczy, ale wsiu ohułom monastyrowi Poczajewskomu i cerkow czerez nas nowuju teper zmurowanuju i apparatami (utensyliami kościelnymi) wodług możnosti naszoje ozdoblenuju, w kotoroj i tiła naszy złożony byti majut, dajemo, darujemo i tym tiepieresznym zapisom naszym wiecznymi czasy zapisujemo..." ${ }^{47}$.

Powyższa suma była przekazana przez Domaszewskich w różnych okresach czasu w postaci pożyczek pod zastaw majątków, wsi i poddanych. Sumę 2,5 tys. zł przekazano kasztelanowi kijowskiemu Romanowi Hojskiemu i ubezpieczone na wieś Uscieczkę i kilku poddanych ze wsi Rydomli; 7 tys. zł staroście krzemienieckiemu Michałowi - Jurju Czartoryskiemu i zabezpieczone wsią Ostrowce. Jednak w 1648 r., podczas powstania Chmielnickiego ta ostatnia została rozgrabiona i spalona przez Tatarów i kozaków. Wieśniaków wybito lub wzięto do niewoli, a tym, którym udało się uniknąć rzezi rozpierzchli się. W obliczu naniesionych szkód, Domaszewscy polecili księciu Czartoryskiemu wypłacić im w zadośćuczynienie poniesionych strat 3 tys. zł. Książę odmówił, a sprawa przeszła pod rozpatrzenie Sądu Ziemskiego w Krzemieńcu, który 14 listopada 1651 r. uznał ich roszczenia za uzasadnione. $Z$ powodu nie zjawienia się Czartoryskiego, sąd wydał zaoczny wyrok na korzyść strony powodowej ${ }^{48}$.

Inną sumę 7 tys. zł przekazano Piotrowi Semnutowi i ubezpieczono na wsie: Szymkowice, Zwonki, Wygorne oraz kilku poddanych $\mathrm{w}$ mieście Kornicy w gminie Lachowce. Wszystkie wymienione majątki, zgodnie z zapisem Domaszewskich z 20 maja 1649 r., miały przejść pod zarząd monasteru poczajowskiego i pozostawać dotąd, dopó-

Żelezo, ihumen poczajowski”. A. Chojnacki, Prawosławije na Zapadie Rossiji, s. 170; A. Chojnacki, Poczajewskaja Uspienskaja Ławra. Istoryczeskoje opisanije, Poczajew 1897, s. 55.

45 A. Chojnacki, Prawosławije na Zapadie Rossii, s. 67. A. Sendulskij, Prepodobnyj Iow igumien poczajewskij, „WEW”, s. 902-903.

46 DATO, F. 258 op. 3, sprawa nr 1169: Wypisi iż grodskich Kremienieckich aktowych knig (1642 - 44), k. 7 - 8. Skarga ihumena Monasteru Poczajowskiego na Andrzeja Firleja za odebranie im 200 wozów drzewa (19. II. 1642 r.). MIPL, nr. 36, s. $69-70$.

47 Darstwiennaja zapiś Anny Hojskoj na ustrojstwo Poczajewskoho monastyra, Poczajew 1908, s. 14

48 Tamże, s. $98-100$ ki zastawcy nie wypłacą jemu pożyczonej oprocentowanej sumy, w zamian za modlitwy za ich dusze: „prereczonym zakonnikom i Starszomu (ihumenowi), w tom monastyru Poczajewskomu buduczomu, po smierci nas obojeho, tyje dobra (majątki) wsi do posesyi swoje wziawszy i w nich aż do oddania sum s tych majetnostiej i nahorody, za szto się z zapisow pokażet, zażywati... A prereczonyja zakonniki, tiepier i napotom w tom monastyre buduczyje, za odpusczeńje hrichow naszych Pana Boha ustawicznie prositi i nabożenstwo za umierłych zwykłoje otprawowati, także z toje prowizyi i cerkow oprawowati (utrzymywać) majut i budut powinni..." 49 .

W 1654 r. Teodor Domaszewski napisał drugi testament, w którym ofiarowuje monasterowi poczajowskiemu znaczne sumy pieniężne znajdujące się w długach u różnych osób. Śmierć nie dała mu jednak zakończyć powyższego zapisu ${ }^{50}$. O niedokończonym testamencie (napisanym bez daty) świadczy wzmianka w zapisie Ewy Domaszewskiej, w którym mówi, że „zeszłi miły małżonek moy pewny od nieodmienny umysł swoy miał, testament ostatniey woli swoiey sporządzić y iuż go począł był pisać, ale mu smierć nie dopustiła" ${ }^{1}$. Nie posiadamy bezpośrednich danych o czasie śmierci Teodora Domaszewskiego. Jednak należy przypuszczać, iż zmarł na początku 1654 r. Dnia 2 czerwca 1654 r. jego małżonka prowadzi już sama proces sądowy z księciem Jurjem - Dymitrem Wiśniowieckim, a Teodor w aktach sądowych tej sprawy jest wspominany, jako zmarły ${ }^{52}$.

Niespokojne czasy Powstania Chmielnickiego niezwykle boleśnie odbiły się na dobrobycie obywateli Państwa Polsko - Litewskiego. Szczególnie wiele zła przyczyniły bezkarnie grasujące szajki złodziejskie oraz tatarskie i kozackie zagony. Korzystając z wewnętrznej słabości Rzeczypospolitej, nieskrępowanie pustoszyły kraj ograbiając bezbronną ludność. W tych niespokojnych czasach Ewa Domaszewska zmuszona była do przejeżdżania z miejsca na miejsce, aby uratować swe życie: „unosząc często y roznie $z$ mieysca na mieysce zdarowie y substantią swoię".

Podczas jednego $\mathrm{z}$ tych przejazdów, 3 marca 1659 r. w drodze ze swego majątku we wsi Kropiwszczynie do Łucka, została napadnięta i ograbiona. Zagarnięto jej min. znajdujące się przy niej dokumenty ziemskie, pomiędzy którymi był także zapis Domaszewskich na rzecz Monasteru Poczajowskiego z 20 maja 1649 r. Pomimo, iż testament wraz $\mathrm{z}$ innymi dokumentami był złożony również w Urzędzie Grodzkim w Krzemieńcu, to jednak powyższa okoliczność bardzo zaniepokoiła Ewę Domaszewską. Księgi Krzemienieckie znajdowały się w tym czasie w wielkim nieporządku. W aktach $\mathrm{z}$ tych czasów spotykamy bardzo częste wskazówki mówiące o opłakanym stanie Ksiąg Grodzkich w Krzemieńcu.

\footnotetext{
49 Tamże, s. 15

50 Tamże, s. 106 - 109. N. Teodorowicz, Zawieszczanije dworianina Fieodora Grickowicza Domaszewskago Poczajewskomu monastyriu ot 1654 goda (nieokonczennoje), „WEW” 29 (1898) 999-1001.

51 Tamże, s. 28.

52 Tamże, s. 113 - 114. N. Teodorowicz, K istorii Poczajewskoj Lawry, „WEW” 4 (1903) 112-121, 4 (1903) 354-362.
} 
Zsyłając się na ten fakt, władze niekiedy odmawiały przyjmowania bądź wydawania kopii dokumentów. W przypadku Domaszewskich istniało niebezpieczeństwo ze strony możliwych protestów przeciwko dziedziczenia przez monaster zapisanych mu majątków. Po przybyciu do Łucka nie mogła się osobiście stawić się do urzędu miejskiego ze względu na słabe zdrowie "na ten czas w niesposobnym barzo zdrowiu zostaiącey" W powyższej sytuacji zwróciła się z prośbą do niejakiego Michała Kalenkiewicza - Strupińskiego, aby zameldował w urzędzie grodzkim w Łucku o mającym miejsce napadzie na tle rabunkowym i zaginięciu dokumentów, który uczynił to 15 marca 1659 r..$^{53}$. Dnia 5 kwietnia 1659 r., z chwilą poprawy zdrowia, zabrała się do ułożenia nowego, bardziej obszernego i szczegółowego testamentu. Oddaliła w nim wszelkie ewentualne roszczenia krewnych ze strony męża i swojej do zapisanych na rzecz monasteru poczajowskiego majątków i sum pieniężnych. Wszystkie ewentualne próby odebrania darowanego majątku monasterowi miały być karane mandatem w wysokości zapisanej monasterowi sumy 16 tys. $500 \mathrm{zł}$ oraz opłatą sądową. Surowość prawna zredagowania nowego testamentu przez Domaszewską wynikała z jednej strony z przekonania, iż to, co poświęcone Bogu nie może być odebrane lub odmienione „aby to, co się iuż Bogu offiarowało, uienło y odmieniono nigdy nie było"; z drugiej widząc skrajne ubóstwo i dewastację monasteru oraz obawiając się aby całkowicie nie ustała w nim „chwała Bożyja”, ofiarowała wspomnianą kwotę w celu jego utrzymania ${ }^{54}$.

Po bezdzietnych Domaszewskich najbliższym dziedzicem, mogącym rościć pretensje do ich majątku oraz zakwestionować prawa monasteru poczajowskiego, był jego bratanek Bazyli Joachinfiusz Gryckowicz Domaszewski. Nie tylko nie wniósł on jakichkolwiek pretensji do zapisanych monasterowi gruntów, ale sam, wyruszając na wojnę ze Szwedami zapisał 28 kwietnia 1656 r. na utrzymanie cerkwi Św. Trójcy 3 tys. zł, pożyczone przez Teodora Domaszewskiego Księciu Lubomirskiemu, które dostał w spadku. Poza tym, pod warunkiem pochowania jego ciała w cerkwi Św. Trójcy obok wuja Teodora Domaszewskiego, zapisał pożyczone Mateuszowi Tołścieckiemu $600 \mathrm{zł}$ oraz 300 zł monasterowi Objawienia Pańskiego w Krzemieńcu i 300 poczajowskiemu ${ }^{55}$. W celu całkowitego uspokojenia monasteru i ciotki Ewy Domaszewskiej wydał dwa zapisy: w pierwszym z 6 kwietnia 1660 r. potwierdził prawa mnichów do zapisanych przez jego wuja majątków, w drugim z 12 września 1662 r. oświadczył, że otrzymał od niego na-

\footnotetext{
53 Tamże, s. $118-119$.

54 „Sama ia, widząc y uważaiąc, ponieważ ten monastyr, będąc z dawna ubogim, a przez te lata woienne zapustoszeniem, wielkim niedostatkiem scisniony iest, aby stąd, strzeż Boże, chwała iego swięta nigdy nie ustawała y nie umnieyszała, tego pilno strzegąc, maiąc insze z ręki Bożey osobne ku wyżywieniu siebie substantią y opatrzenie swoye, do używania y realney spokoyney posessiey monastyra y wielebnych oycow poczaiowskicch, iako za mocą pierwszego nas oboyga wliwkowego zapisu przezżeczone dobra podałam...., Tamże, s. 23.

55 Tamże, s. 126 - 128. N. Teodorowicz, K istorii Poczajewskoj Lawry, „WEW” 14 (1903) 431-435.
}

leżytą część majątku i nie rości żadnych pretensji do pozostałej jego części ${ }^{56}$.

Zapisane monasterowi majątki zostały całkowicie spustoszone i wyludnione podczas prowadzonych działań wojennych ${ }^{57}$. W drugim testamencie Domaszewskiej monaster otrzymał, więc prawo do zasiedlania ich swymi chłopami, stawiania zagród, młynów, grobli w stawach, oddawania $\mathrm{w}$ arendę lub zastaw pieniężny. Zaznaczyła jednak, aby pieniądze otrzymywane z majątków były wykorzystywane jedynie na utrzymanie monasteru i upiększenie nowo wzniesionej świątyni. Niezwykle ważnym jest jeden z warunków zapisu mówiącego, iż wszystkie sumy pieniężne i majątki mają należeć do monasteru do tej pory, dopóki będzie w nim zachowana wiara prawosławna. W przypadku przejścia na unię należy przekazać zapisany przez fundatorkę majątek innemu monasterowi pozostającemu przy prawosławiu..$^{58}$

Należy przypuszczać, iż Ewa Domaszewska nie uczyniła tej istotnej konkluzji przypadkowo. Pomimo, że jej przyczyny nie zostały ukazane w testamencie, to niewykluczone, że po śmierci św. Hioba ze strony unitów były próby przejęcia monasteru. Dlatego fundatorka cerkwi Św. Trójcy zastrzega w swym testamencie wieczne pozostawanie przy prawosławiu monasteru poczajowskiego. Powyższy warunek zapewne silnie wpłynął na jego losy. Być może od tego faktu zależało tak długie pozostawanie przy wierze prawosławnej aż do początku XVIII w., gdy ostatnim monasterom na Wołyniu została narzucona unia.

Drugi zapis Domaszewskiej wykonany 26 kwietnia 1659 r. został podpisany przez zaproszonych przyjaciół: Seweriusza Korczakowskiego, Michała Ledochowskiego i Michała Króla Łaźniowskiego. Zapis był osobiście przez

$56 \quad$ Tamże, s. 128 - 130, 132 - 136. N. Teodorowicz, K istorii Poczajewskoj
Lawry, „WEW” 15 (1903) 457-461.

57 „Przez te woienne lata funditus ogniem y mieczem są zniesione, a za tym żadnego tam poddanego, dworu, stawu, młyna y inszego pożytku nie został, y monastyr temiż laty zubożał y spustoszał ..... Tamże, s. 20.

58 „... y tych dóbr dziedzicom y nikomu inszemu nie zostawuiąc y nie wymuiąc, na wieczne czasy się z nich zrzekaiąc siebie, successory, blizkie krewny nas oboyga zapisami naszemi, iako pirwszym, tak y tym poslednim, od nich odalaiąc, samemu temu monastyrowi Poczaiowskiemu obszczeżytelnomu, cerkwi Przenasswiętsey Troycy y wielebnym oycom, w nim starszemu y braci iego teraz nie yszym y następcom ich Regóły Swiętego Bazylego Wielkiego obszczeżytelnym, to iest wespół w iednakim porządki żyiącym ziednoczenie, spolnie, bez osobnosci, wedłóg pomienioney Reguły chowaiącym, w Nieuniey zawsze y wiecznie, naydiącym się. Co waruię pod odpadnieniem od tych summ, im teraz cedowanych, który za przyięciem, strzeż Boże, przez nich uniey, do inszego w nieuniey będące monastyra, tam, gdzie intentiey naszey za duszy nasze dosyć się będzie działo, pastyrze nasze, własni duchowni prawosławni według uwagi swey, aby prowisia dochodziła, obrócić będą mogli y wolni”. „Darstwiennaja zapiś Anny Hojskoj na ustrojstwo Poczajewskoho monastyra", s. 22 - 23. Powyższy warunek rok po śmierci Ewy Domaszewskiej w 1666 r. został zniesiony przez Sąd Trybunalski. Warunek zmarłej fundatorki dotyczący wstrzymania wypłaty kwoty 16 tys. $500 \mathrm{zł} \mathrm{w}$ przypadku przejścia moansteru na unię został uznany przez Sąd Trybunalski za niesprawiedliwy, albowiem zwracał się przeciwko Kościołowi Unickiemu. Dlatego decyzją sądu był skasowany i na wieczne czasy zniesiony. Oświadczył on, że powyższa kwota powinna być wypłacona monasterowi nawet w przypadku przyjęcia unii. Pomimo, iż prawne znaczenie testamentu Domaszewskiej w stosunku do powyższego warunku zostało zniesione, tym jednak jego moralny wpływ na mieszkańców monasteru pozostawał w całej swej mocy. 
nią złożony w Sądzie Grodzkim w Krzemieńcu i wpisany do akt grodzkich. Tego samego dnia wspomniane osoby podpisały również umowę, zawartą pomiędzy ihumenem Doroteuszem Treciakowiczem (w imieniu całej wspólnoty) a Ewą Domaszewską, odnośnie zapisanych przez nią gruntów. Przełożony wydał jej zapis, w którym deklarował jej dozgonne prawo korzystania z dochodów majątków w Uścieczku i Ostrowcu. Zastrzega jednak, że jeśliby z winy monasteru poniosła jakiekolwiek straty, to posiada prawo wnieść skargę do metropolity kijowskiego lub prawosławnego biskupa łuckiego ${ }^{59}$.

Kolejny testament został napisany niedługo przed jej śmiercią 8 grudnia 1665 r. Ostatnie lata spędziła w monasterze poczajowskim. Prosiła w nim, aby jej pochówek odbył się według obrządku wschodniego Kościoła prawosławnego w cerkwi Św. Trójcy przy grobie jej męża. Wyraziła także swe życzenie, aby odznaczał się on skromnością, bez zbędnego przepychu i uroczystego charakteru, jedynie w obecności jej przyjaciół i możliwie licznie przybyłych ubogich. Potwierdzając ważność poprzednich zapisów fundacyjnych na rzecz mnichów (sporządzonych osobiście i przez jej męża), zwróciła się do swych dłużników, aby bez żadnych sprzeciwów zwrócili pożyczone u niej pieniądze mnichom. Cały swój majątek ruchomy, składający się ze srebrnych i złotych przedmiotów przeznaczyła na upiększenie wspomnianej cerkwi. Mając w pamięci wierną służbę swego krewnego, a obecnie mnicha poczajowskiego Ławrencjusza Biereżyckiego, prosiła o wydanie mu z arendy wsi Uścieczki 100 zł a słudze Kowalskiemu 30 zł i konia. Z obawy przed możliwymi nieporozumieniami w stosunku do mnichów ze strony Wojewody Wołyńskiego Księcia Michała - Jurja Czartoryskiego, zobligowała Domaszewską do zwrócenia się w swym testamencie z prośbą, aby bacząc na zasługi męża i jego przodków nie wzbraniał im w korzystaniu z majątku wsi Ostrowiec. Przestrzegała przed klątwą i Sądem Bożym przeciwników swej ostatniej woli. Pod ostatnim

\footnotetext{
59 Darstwiennaja zapiś Anny Hojskoj na ustrojstwo Poczajewskoho monastyra, s. 131 - 132. N. Teodorowicz, K istorii Poczajewskoj Lawry, „WEW” 14 (1903) 435-437.
}

testamentem zapisanym w Monasterze Poczajowskim złożyli podpisy: Adam Świętojański, Bogdan Isernicki i archimandryta owrucki Teodor Krechowiecki. Dnia 9 stycznia 1666 r. ihumen Efrem Szacki wniósł do Ksiąg Grodzkich w Krzemieńcu powyższy zapis ${ }^{60}$.

Góra poczajowska zasłynęła na Rusi po cudownym objawieniu się tam Matki Bożej. Przypuszczalnie, już w 1240 r. uciekający przed hordami tatarskimi mnisi z Kijowa znaleźli schronienie w pobliskich pieczarach. W 1559 r. właścicielka tych ziem Anna Hojska ufundowała dla żyjących w pieczarach mnichów monaster prawosławny oraz przekazała cudowną ikonę Matki Bożej. Najwybitniejszym ihumenem monasteru poczajowskiego był św. Hiob Zalizo. Po raz pierwszy został wybrany wyłącznie przez mnichów na nowego przełożonego monasteru, czwartego od czasu wprowadzenia w monasterze reguły cenobitycznej. Drugimi wybitnymi fundatorami monasteru poczajowskiego stali się małżonkowie Domaszewscy. Swymi wysiłkami włożonymi w wzniesienie kamiennej cerkwi, znacznymi nadaniami pieniężnymi i ziemskimi przeznaczonymi na jej upiększenie i utrzymanie samego monasteru, pragnęli wynagrodzić straty i zniszczenia naniesione przez możnowładcę Firleja oraz powstanie kozackie, i tym samym nie dopuścić do całkowitego upadku i ustania życia monastycznego na Górze Poczajowskiej. Z tego względu ich imiona zostały tak mocno podkreślone w dziejach głównego ośrodka duchowego na Wołyniu ${ }^{61}$.

\footnotetext{
60 Tamże, s. $27-31$.

${ }^{61}$ W Domu Metropolitów Prawosławnych w Warszawie zachował się zabytkowy, malowany na płótnie obraz. Przedstawia w całej postaci Teodora i Ewę Domaszewskich, podtrzymujących na rękach wzniesioną przez nich cerkiew Św. Trójcy. Wokół herbu Teodora znajdują się początkowe litery H.T.D.K.G.P.K., co znaczy: Hryckiewicz Teodor Domaszewski Komornik Granic Powiatu Krzemienieckiego, a wokół herbu jego małżonki - B.E.D.K.G.P.K., tj. Bogobojna Ewa Domaszewska Komornikowa Granic Powiatu Krzemienieckiego. U podstawy obrazu widnieje napis: Fundatorowie starey cerkwi w Poczaewi W.W. (Woiewodstwa Wolynskiego) Teodor i Ewa Domaszewsky Komornikowstwo Granicy Krzem. Ro 1649. Obraz więc został namalowany bądź w okresie, gdy na miejsce wybudowanej przez Domaszewskich starej cerkwi została wzniesiona przez Mikołaja Potockiego w II poł. XVIII w. nowa świątynia, gdyż umieszczony na nim napis nazywa ich fundatorami starej cerkwi, bądź jest kopią bardziej
} starożytnego oryginału.

\section{Bibliografia}

Źródła:

Akty, otnosiaszcziesja k istorii Zapadnoj Rossii, sobrannye i izdannye Archeograficzeskoju Komissieju, t. 4, Sankt-Petersburg 1851.

Archeograficzeskij sbornik dokumentow otnosjaszczichsja $k$ istorii Sewero-Zapadnoj Rusi, izdawaemyj pri uprawlenii Wilenskogo uczebnogo okruga, t. II, Wilna 1904.

Dierżawnyj Archiw Tarnopolskoj Oblasti, Fond 258 (Počaevski Arhiv), opis 3, sprawa nr.: 1165/1,1169.

Materiały po istorii Poczajewskoj Ławry, red. W. Lewickij, t. 1, Poczajew 1912.

Pamiatniki izdannyje wremiennoj Komisijej dla razborki drewnich aktow wysoczajsze uczreżdennoju pri Kiewskom wojennom, Podol'skom i Wolynskom general-gubernnatore, t. IV/1-2, Kijew 1859.

Pczeła Poczajewskaja. Izbornik nazidatel'nych pouczenij i statej, sostawlennych i spisannych prepodobnym Iowom, igumenom Ławry Poczajewskoj (1581-1651), red. prof. N. I. Pietrowa, Poczajów 1884.

\section{Opracowania:}

Amwrosij (Łatockij) archim., Skazanije o Poczajewskoj Uspienskoj Ławre, Poczajew 1787. 
Antonovič S., Korotkii istoričnii naris Počaïvs'koï Uspins'koï Lavri, Kremianec 1938.

Baliński M., Lipiński T., Starożytna Polska, Warszawa 1844, t. 2/2.

Batiuszkow P. N., Wołyń. Istoriczeskija sud'by Jugo - Zapadnago kraja, S - Petersburg 1888, s. 124.

Bieńkowski L., Organizacja Kościoła wschodniego w Polsce, [w:] Kościół w Polsce. Studia nad historią Kościoła Katolickiego w Polsce, red. J. Kłoczowski, t. 2/2, Kraków 1969, s. 840 - 855.

Boniecki A., Herbarz Polski, t. VII, XII, W - wa 1904.

Borkowski A., Dzieje drukarni poczajowskiej, [w:] red. W. Stępniak-Minczewa, Z. J. Kijas, Klasztory i kultura krajów słowiańskich, Kraków 2001, s. 279-303.

Charlampowicz K., Iosif Kurcewicz, archijepiskop Suzdalskij, Kazań 1900, s. 15.

Chodynicki K., Kościół prawosławny a Rzeczypospolita polska. Zarys historyczny 1370-1632, Warszawa 1934.

Chojnacki A., Poczajewskaja Uspienskaja Ławra. Istoryczeskoje opisanije, Poczajew 1897.

Chojnacki A., Prawosławije na Zapadie Rossii ili Patieryk Wołyno - Poczajewskij, Moskwa 1888.

Doroszenko D., Narys istoriji Ukrajiny, t. I, Warszawa 1932.

Dubilko J., The Pochaiv Monastery in the history of our nation, Vinnipeg 1986.

Gołubjew S., Kijewskij mitropolit Pietr Mohiła i jego spodwiżniki, t. II, Kijów 1898, s. 25.

Gora Počaevska, Poczajew 1806.

Grabowski T., Ostatnie lata Melecjusza Smotryckiego. Szkic do dziejów literatury unicko-prawosławnej wieku XVIII, [w:] Ksiegga pamiątkowa ku czci Bolesława Orzechowicza, Lwów 1916, s. $318-321$.

Hruszewśkyj M. S., Istorija Ukrajini - Rusi, t. VII, Kijiw-L’wiw 1909.

Konieczny F., Święci w dziejach narodu polskiego, Kraków Warszawa 1985.
Lewickij W., K woprosu o wremieni osnowanija Poczajewskoj Lawry i o pierwoj ustroitielnice jeja Annie Gojskoj, „WEW” 6 (1913) 96-100, 7 (1913) 126-128, 8 (1913) 138-142, 9 (1913) 165-167, 11 (1913) 201-204.

Mironowicz A., Kościół prawosławny w dziejach dawnej Rzeczypospolitej, Białystok 2001.

Opisanije Poczajewskija Uspienskija Ławry, Poczajew 1878.

Orłowski J. P., Uczastije Zaporożskich kozakow $w$ wostanowlenii ijerusalimskim patriarchom Teofanom prawosławnoj jużno russkoj cerkownoj ijerarchii w 1620 g, [w:] „Trudy Kijewskoj - Duchownoj Akademii", Kijew 1905.

Osinskij A. S., Mieletij Smotrickij, Kijew 1912.

Pelesz J., Geschichte der Union der ruthenischen Kirche mit Rom von den ältesten. Zeiten bis auf die Gegenwart, t. II, WürzburgWien 1881.

Petruszewicz A., Istoriczeskoje izwiestije o drewniej Poczajewskoj obitieli, „Galiczanin”, 1 (1863) 158-161.

Sendulskij A., Prepodobnyj Iow igumien poczajewskij, „WEW”, 22 (1875) 874-909, 23 (1875) 951-965.

Serczyk W. A., Na dalekiej Ukrainie. Dzieje Kozaczyzny do 1648 roku, Wrocław-Kraków 1984.

Teodorowicz N., K istorii Poczajewskoj Lawry, „WEW” 14 (1903) 425-449.

Teodorowicz N., Zawieszczanije dworianina Fieodora Grickowicza Domaszewskago Poczajewskomu monastyriu ot 1654 goda (nieokonczennoje), „WEW” 29 (1898) 999-1001.

Tomkiewicz W., Cerkiew dyzunicka w dawnej Rzeczypospolitej Polskiej 1596-1795, „Przegląd Powszechny”, CIC (1921-1922) $161-163$.

Tripolskij N., K istorii drevniago pravoslavnago Počaevskago monastyria na Volyni, „Wołynskija Eparchialnye Wedomosti” 15-18 (1896) 570-575, 607-617, 672-675, 687-710.

Woliński J., Polska i Kościót prawosławny. Zarys historyczny, Lwów 1936. 